\title{
The Influence of College Teachers' Cultural Quality on College Students' Cultural Quality
}

\author{
Le Gao \\ College of Marxism, Jilin Agricultural University, Changchun 130118, China
}

Keywords: College students; Cultural quality; College teachers; Current situation; Way

\begin{abstract}
To improve college students' cultural quality is related to whether China's strategic goal of constructing socialist modernization can be achieved and the major strategic issue that whether the Party's basic route can be unwavering for one hundred years. Therefore, each college pays full attention to this issue. However, with the rapid development of the society and economy, contemporary college students are also suffering from the impact of various cultural trends, value orientation is increasingly diversified and cultural quality education's guiding role is becoming increasingly prominent. There are many factors that affect the cultural quality of college students, and teachers' cultural quality plays an important role in these influencing factors. Therefore, in order to improve the cultural quality of contemporary college students, it is necessary to first improve teachers' cultural quality. [1].
\end{abstract}

\section{Introduction}

As an important human resource for the development of the nation, college students are the hope of contemporary development of China in the new century, and cultural quality education is the basis for the comprehensive development of college students, effective implementation of ideological and political education and the cultivation of ideals and beliefs. [2] Among various factors affecting college students' cultural quality, teachers' cultural quality occupies an important position. Teachers directly impart knowledge to students, and education concepts, talent cultivation mode, teaching contents and teaching methods are all in all implemented and reflected by teachers through their own words and deeds during the teaching process. Therefore, in order to strengthen college students' cultural quality, teachers' cultural quality must first be improved.

\section{Great Importance of College Teachers' Cultural Quality on Improving College Students' Cultural Quality}

Colleges and universities are not only an important base to cultivate talents and conduct scientific researches, but also a significant area to shape talents and carry out spiritual production. This characteristic of colleges and universities determines that it is the responsibility of all the teachers to cultivate a people with comprehensive development in morality, intelligence and sports needed by the society. College teachers subtly influence students' ideology and personality through inheriting, disseminating, developing and creating science and technology as well as cultural knowledge of human beings. [3] Cultural quality is the scientific and cultural knowledge structure and the degree that teachers should have. It is the most basic quality for teachers in education with positive significance to the improvement of college students' cultural quality.

Improving teachers' cultural quality is the milestone to improving college students' cultural quality.

First of all, Teachers are the Disseminators of Knowledge. Knowledge is the most valuable wealth of teachers. A teacher's knowledge level directly affects to what extent his/her individual ability can be played and students' dependence on teachers. Practices have proved that the more professional knowledge teachers master, the more obvious the teaching effect is and the greater effect teachers have on students. And a teacher with poor cultural quality and insufficient knowledge cannot impart knowledge and skills to students in simple languages nor cite various examples, which would naturally not bring much benefit to students. Thus, teachers need to constantly enrich and update their 
professional knowledge and delve into more fields of knowledge, such as literature, history, philosophy, music, sports, arts, mathematics, physics and chemistry, astronomy, and geography so as to make it possible for college students to improve their cultural quality. [4]

Secondly, Teachers Influence College Students' Personality Development. Education is mainly realized during the teaching process, and while students are getting along with teachers, teachers' personality, world outlook, value, ideals and interests will profoundly influence students. As Confucius said: "If you are upright, people will spontaneously follow you; if you are not upright, you will be followed by none even if there is an order." [5] Teachers' words and deeds play a subtle role in influencing college students' growth. It is usually said that teachers should set themselves as an example, which emphasizes teachers' important role in shaping college students' beautiful minds and high quality.

\section{Current Status of College Teachers' Cultural Quality}

To implement cultural quality education has proposed higher requirements for college teachers' cultural quality. It can be seen that the overall level of college teachers' cultural quality is not high and college teachers themselves need to improve their own quality. College teachers should at least have the four aspects of quality to well implement cultural quality education. The scientific outlook of the world, education and life is the core of teachers' cultural quality; extensive knowledge in literature and history and profound artistic accomplishment are the connotations of teachers' cultural quality; good oral expression and higher calligraphy level are the basis of teachers' cultural quality; elegant demeanor, appearance and temperament are the comprehensive demonstration of teachers' cultural quality. [6] Due to the long-term influence of planned economy and exam-oriented education, there are still many shortcomings and defects in college teachers' cultural quality, which greatly hinders the implementation of cultural quality education. For example, there is a lack of humanistic spirit. At present, many college teachers merely regard scientific knowledge as a tool. Humanities standard cannot be used to accurately determine their own behaviors, and teachers cannot make correct and rational judgment on things outside the scope of their expertise. Therefore, teaching only stays on the surface of spreading natural knowledge, and scientific spirit and humanistic spirit cannot be implemented throughout teaching. [7] There is a lack of literature and history knowledge. Some teachers pay attention to science but ignore arts or even deny the value of social science without necessary understanding of the essence of Chinese and foreign culture while lacking knowledge of literature and history. During teaching, attention is only paid to cultivating students' logic thinking and the cultivation of imaginal thinking is ignored. Teachers cannot infect the classroom with lofty emotions, so students lack imagination and have single thinking, making it difficult to achieve all-round development. Low artistic cultivation, which is due to the influence of exam-oriented education during growth. At present, most college teachers lack knowledge in music and art, and some teachers are lonely and lazy in communication, and they are not good at expressing, so the classes are dull and the teaching methods are rough and simple, lacking proper temperament and demeanor. Thus, it is difficult to find the style of a scholar that universities should have. [8]

\section{Paths to Improve College Teachers' Cultural Quality}

There are a variety of ways to improve teachers' cultural quality and the most effective and lasting way is to enrich yourself and improve yourself through continuous learning.

First of all, Teachers Must Constantly Enrich and Update Their Own Expertise. Modern technology is rapidly developing, the aging period of knowledge has been shortened from 80-90 years in the 18th century to 15 years, and that of some subjects has even been shortened to 5-10 years or shorter, which makes the concept of one-time education undergo a fundamental change. [9] If a person does not timely supplement and update their own knowledge, he/she will be eliminated by the times. Therefore, it is necessary to make education throughout a person's life, which naturally poses higher requirements for teachers, the knowledge disseminators. Otherwise, they will become unable to bear 
the glorious mission of cultivating the next generation of talents.

Second, Teachers Should Develop Their Own Multi-Channel Teaching Ability. Modern teachers' good teaching ability is an important guarantee to improve the quality and efficiency of teaching. The teaching ability of modern teachers is characterized by many channels, or the communication of teaching information is done through various channels. The main channels of instruction are: sound channel, character channel, action channel, time and space channel, integrated channel and so on. It can be seen that the teaching expression is multi-channel and each channel has its own characteristics. Now, teachers should be flexible in teaching according to the need to use a variety of channels to pursue the expression of teaching "three-dimensional" effect, so that teaching become superb art. [10]

Thirdly, Teachers Should Improve their Self-Regulation and Control Ability. Nowadays, teachers' self-control ability includes two aspects: one is based on the objective needs of the ability to control their own main structure. Today's modern teachers face a highly changing society, but also need to have a strong self-learning ability, in order to enrich the new knowledge, adjust the knowledge structure; need to have a strong self-cultivation ability, to continuously improve their ideological and moral cultivation; sensitive to accept the new ability from student feedback, to adjust their behavior and book at any time to the teaching plan and procedures to make the teaching process to the optimal state. The second is to regulate their own mood, emotional and emotional ability. Modern teachers should always maintain the best mental state in front of students and infect and affect students with a happy and optimistic state of mind.

Finally, Teachers should Get Involved in Various Aspects of Knowledge and Learn Widely from Others' Advantages to Improve their own Knowledge Structure. The current development of subject is featured by constant segmentation and comprehensive while different subjects are overlapped and penetrated with each other. [11] Each subject is horizontally connected with other subjects, so if teachers only focus on the textbook, they will obviously be separated from the times. And in order to keep pace with the times, teachers need to broaden their scope of knowledge, have more extensive interests and hobbies and get involve in more knowledge fields so as to make their knowledge structure more reasonable. It should be particularly emphasized that each teacher should strengthen their artistic accomplishment, which is vital for college students to cultivate correct outlook on life and value and create ideal personality.

\section{Summary}

College students are the hope of contemporary development of China in the new century, and cultural quality education is the basis for the comprehensive development of college students, Among various factors affecting college students' cultural quality, teachers' cultural quality occupies an important position. Therefore, in order to strengthen college students' cultural quality, teachers' cultural quality must first be improved.

\section{References}

[1] L.X.Heng: On the Optimization and Innovation of Political and Ideological Education Environment at Colleges and Universities [J]. Journal of Chongqing University. 2011(06).

[2] L.H.Lin:Political and Ideological Education in the New Century [J]. Weekly Educational Journal, 2010(08).

[3] L.D.Wei:On the Influence of Political and Ideological Education Environment at Colleges and Universities on College Students' Cultural Quality [J]. Heilongjiang Higher Education Research, 2011, (3):108-110.

[4] L.Yun: On the Influence of Political and Ideological Education Environment at Colleges and Universities on College Students' Ideological Morality [J]. Journal of Huanggang Normal University, 2012, 32(2):34-35. 
[5] L.G.Ye, Z.Li:On the Influence of Ideological and Political Education at Colleges and Universities on College Students [J].Journal of Hubei Correspondence University, 2011, 24(6):37-38.

[6] J.A.Qun: Li Zhen. On the Improvement of Ideological and Political Education in Colleges and Universities Based on the Present Situation of College Students' Needs [J]. Journal of Ideological \& Theoretical Education, 2012, (4):103-105.

[7] D.Yan:Cheng Jing, Zhang Ruiyong et al. To give full play to the role of ideological and political education in cultivating college students' innovative thinking [J]. Journal of Ideological \& Theoretical Education, 2012, (9):118-120.

[8] L.H.Yan:On the Construction of Ideological and Political Education Environment in Colleges and Universities [J]. Heilongjiang Higher Education Research, 2015, 2 (9): 47-50.

[9] S.B.Yi: An Effective Way to Improve Teachers' Quality in Ideological and Political Theory Course in Colleges and Universities [J] . Higher Agricultural Education, 2011(04).

[10]L.Y.Xian:On the Quality of Teachers in Quality Education [J]. Journal of Shanxi College Social Sciences, 2009, (1).

[11]S.S.Zhen:The Effect of Good Cultural Quality of College Teachers on Cultivating College Students' Ideological Quality [J] Science and Education, 2006.08 